Creative commons User License: CC BY-NC-ND

Abstracted by: EBSCOhost, Electronic Journals Service (EJS), Google Scholar, Journal Seek, Scientific Commons,

Food and Agricultural Organization (FAO), CABI and Scopus
Journal of Agricultural Extension

Vol. 22 (2) June, 2018

ISSN(e): 24086851; ISSN(Print); 1119944X

http://journal.aesonnigeria.org

Email: editorinchief@aesonnigeria.org

\title{
Economics of Pineapple Marketing in Anambra State, Nigeria
}

https://dx.doi.org/10.4314/jae.v22i2.14

\section{Enibe, David O.}

Department of Agricultural Economics and Extension, Chukwuemeka Odumegwu Ojukwu University, Igbariam Campus, Anambra State, Nigeria. Email:

enibedav@yahoo.com , Tel. +2348137829887

\section{Eze, Ada 0.}

Department of Agricultural Economics and Extension, Igbariam Campus, Chukwuemeka Odumegwu Ojukwu University, Igbariam Campus, Anambra State, Nigeria.

Tel. +2348034180403

\section{Ugwuoke, Boniface C.}

Enugu State University of Science and Technology, Nsukka, Nigeria.

Email: chukwkaugwuoke@gmail.com Tel. +2348160331772

\section{Abstract}

The study analysed the economics of pineapple marketing for entrepreneurial utilization in Anambra State Nigeria. Data for the study were collected from 104 respondents which comprised of 40 retailers and 64 wholesalers randomly sampled from eight markets of the study area (4 markets from each of the two cities). The markets are Main market, Ose, Ochanja and bridge-head market areas were selected from Onitsha commercial city while Eke, Nkwo Amaenyi, Aroma junction and Nnamdi Azikwe University(UNIZIK) temporary site market areas were chosen from Awka Capital city. The markets were purposively selected because they are where higher concentration of middlemen in pineapple business are commonly found in the cities. Descriptive statistics and gross margin analysis were used in data analysis. The study inter alia revealed that the majority (62\%) of pineapple consumed in the study area were sourced by the middlemen from outside Anambra State, showing that the state is not selfsufficient in the crop's production. Respective return on investment made by the wholesalers and retailers were (0.23 and 0.32) indicating that the trade on the crop is profitable. It was further revealed that high transportation cost and lack of fund to increase business scale were the main constraints of the pineapple traders. The study concluded that investment opportunities exist on the crop's market, production and processing and therefore recommends that the potential traders and entrepreneurs should exploit the crop's business potentials.

Keywords: Pineapple, entrepreneurs, business 
Creative commons User License: CC BY-NC-ND

Abstracted by: EBSCOhost, Electronic Journals Service (EJS),

Google Scholar, Journal Seek, Scientific Commons,

Food and Agricultural Organization (FAO), CABI and Scopus
Journal of Agricultural Extension

Vol. 22 (2) June, 2018

ISSN(e): 24086851; ISSN(Print); 1119944X

http://journal.aesonnigeria.org

Email: editorinchief@aesonnigeria.org

\section{Introduction}

The goal of marketing research is to supply information concerning the needs and desires of customers, marketing opportunities available in different products, goods or services, and the changing behaviours and customers' regular buying order or pattern (Sally, Lyndon, William and Ferrell 2006). Fruits are described as the flesh and sweet products of plants that contain seed or seeds and which can be eaten as foods (Maurice, 2012). They are popular, rich in vitamins and mineral elements which are essential in the diet of all classes of people such as the children, pregnant women, nursing mothers, the sick and old people (Technical centre for Cooperation (CTA), 2007). In different towns and cities people spend a lot of money in the purchase of fruits from many different marketing outlets which include shops, supermarkets, assembly markets, restaurants, and hotels (CTA, 2007). This results to good performance of many fruits business. For example, activities of the banana market structure were found to be almost optimum with good performance (Enibe, Chidebelu, Onwubuya, Agbo and Mbah,2008). Hence, considerable income generation opportunities appear to exist in fruits' business. It has the capacity to generate foreign exchange because its trade is seen to be oriented towards developed countries (Iwuchukwu, Udoye and Onwubuya 2013;). Such opportunities in many fruits are being neglected by the unemployed, entrepreneurs and potential traders in Nigeria.

Nigeria's annual production of pineapple is about 1.4 million MT and ranks $7^{\text {th }}$ position in the world (Iwuchukwu Nwobodo and Udoye, 2017). The crop is therefore produced, marketed, consumed and considerable amount of income generated from it by many farm families in Nigeria (Iwuchukwu Nwobodo and Udoye, 2017). The crop can be grown from the suckers or its fruits' crowns during the seasons or off-seasons (Olayinka, 2013). Pineapple is a delicious fruit that has fine flavour, highly nutritive and a good source of vitamin A, B, B6, C, Copper, 15\% sugar, and dietary fibre (Iwuchukwu Nwobodo and Udoye, 2017).

The content exposes the fruit as good raw material in confectionary industries for production of different products such as sweet, household additives, fruit drinks and wine. In evidence, Idise (2012) revealed that its wine had similar characteristics with that of palm wine. Also, pineapple offers ornamental values, symbolizes expensive or luxurious living and welcome to visitors (Olayinka, 2013). Pineapple facilitates protein digestion, combat loss of memory and sadness and offers outstanding cerebral toner values (Iwuchukwu et al, 2013). The leave is used as feed to farm animals and can yield fibre which may be used for paper production (Olayinka, 2013). Pineapple is observed to be one of the leading commercial fruits in international market (Iwuchukwu Nwobodo and Udoye, 2017). In Southeast Nigeria, the crop's business or economic opportunities seems not adequately utilized by entrepreneurs, unemployed and traders. One of the reasons for the underutilization may be because its commercial potentials such as its low initial capital requirements, moderate marketing costs and considerable net return on investment have not been adequately exposed and encouraged. In support, 
Creative commons User License: CC BY-NC-ND

Abstracted by: EBSCOhost, Electronic Journals Service (EJS),

Google Scholar, Journal Seek, Scientific Commons,

Food and Agricultural Organization (FAO), CABI and Scopus
Journal of Agricultural Extension

Vol. 22 (2) June, 2018

ISSN(e): 24086851; ISSN(Print); 1119944X

http://journal.aesonnigeria.org

Email: editorinchief@aesonnigeria.org

Iwuchukwu et al (2013) saw the need for encouragement of its production and marketing trends.

In view of the above, the study answered the following research questions: What are sources of the pineapple marketed in the study area? is pineapple business in the study area profitable? what are the major problems of the pineapple traders?

\section{Objectives of the Study}

The broad objective of the study was to analyse pineapple marketing in Anambra State, Nigeria. The specific objectives were to:

1. determine the sources of pineapple marketed;

2. examine the profitability of pineapple marketing and

3. determine the problems of pineapple marketing.

\section{Methodology}

The study was conducted in Anambra State of Nigeria. The state is located in Southeast Nigeria. It lies between latitude $5^{0} 38^{\prime} \mathrm{N}$ to $6^{0} 47^{\prime} \mathrm{N}$. and longitude $6^{0} 36$ ' $\mathrm{E}$ to $7^{0} 21^{\prime}$. The State is bounded in the North by Kogi State, in the South by Imo State, in the east by Enugu State and in the west by River Niger and Delta State. The state has twenty-one local government areas (LGA), four agricultural zones and many assembly markets in most of the towns or village communities and cities. The data for the study were collected from primary and secondary sources. The secondary data were sourced from Journals, research documents, bulletins and books. The primary data were purposively collected from city markets of Onitsha and Awka. Onitsha was purposively chosen because it contains the biggest market in West Africa (Enibe et al, 2008) while Awka was purposively selected because it is the capital city of the study area. Main market, Ose, Ochanja and bridge-head market areas were selected from Onitsha commercial city while Eke, Nkwo Amaenyi, Aroma junction and UNIZIK temporary site market areas were chosen from Awka Capital city. The city market areas were chosen because they are where higher concentrations of middlemen in pineapple business are commonly found. From each of the 8 market areas of the two cities, 5 retailers and 8 wholesalers were purposively selected and interviewed using questionnaire. This gave a sub total of 20 retailers and 32 wholesalers from the 4 market areas in each of the cities and a grand total of 104 pineapple marketers. The respondents were purposively selected because the sample frames of the pineapple middlemen in the markets were not known. Two sets of pretested questionnaire (one for the retailers and the other for the wholesalers) were administered to the respondents.

Data were realized using descriptive statistics and gross margin (GM) analysis. Gross margin is the difference between total revenue (TR) and total variable costs (TVC). Also assessed for the analysis were the total variable costs (TVC), total fixed costs (TFC), total costs (TC), net marketing income (NMI) and net return on investment (NROI). The 
Creative commons User License: CC BY-NC-ND

Abstracted by: EBSCOhost, Electronic Journals Service (EJS),

Google Scholar, Journal Seek, Scientific Commons,

Food and Agricultural Organization (FAO), CABI and Scopus
Journal of Agricultural Extension

Vol. 22 (2) June, 2018

ISSN(e): 24086851; ISSN(Print); 1119944X

http://journal.aesonnigeria.org

Email: editorinchief@aesonnigeria.org

$\mathrm{NMI}$ is the difference between gross margin and TFC while NROI is the ratio of net marketing income to the total cost. The business enterprise with higher $\mathrm{NROI}$ is considered to be the most profitable (Abbot and Makeham, 2000).

\section{Results and Discussion}

\section{Sources of the Pineapple Marketed in Anambra State}

The result in Table 1 shows that the majority of the respondents $(61.5 \%)$ sourced their pineapple stock from outside Anambra State. The Pineapple from outside the State was sourced from places such as Edo State, Benin; Delta State, Agbo. On the other hand, $38.5 \%$ of the pineapple stock was sourced from within Anambra State (from communities such as Igbariam, Ogidi, Otuocha, and Nkpo).

Table 1: Sources of the pineapple marketed in Anambra State

\begin{tabular}{lc}
\hline Sources of pineapple marketed & Percentage \\
\hline Outside Anambra & 61.5 \\
Within Anambra & 38.5 \\
Total & 100 \\
\hline
\end{tabular}

Source: Field

\section{survey, 2016}

The implication is that the pineapple consumed or processed in Anambra State is mainly produced outside the State. This reveals that the state is not self-sufficient in pineapple production indicating the need for its increased production to meet its current demand and supply situation. The result also indicates that the state has available market on the crop and that entrepreneur and other farmers not previously involved in its production can invest in this direction. It further reveals that pineapple is highly demanded in the study area and that there is the need to encourage current pineapple farmers for increased production of the crop. The result appears convincing because the state is reported to have large population and the biggest market in West Africa (Enibe et al, 2008). The result also supports Iwuchukwu, Udoye and Onwubuya (2013) whose study saw the need to encourage pineapple farmers for increased output of the crop. 
Creative commons User License: CC BY-NC-ND

Abstracted by: EBSCOhost, Electronic Journals Service (EJS),

Google Scholar, Journal Seek, Scientific Commons,

Food and Agricultural Organization (FAO), CABI and Scopus

Marketing Costs and Returns of Pineapple marketing

Table 2 reveals that wholesalers and retailers made a gross margin of N3,779,760.00 and N741, 840.00 respectively. The traders made a mean net marketing income of N34, 777.37 and N10, 624.21 respectively. Table 2 shows that the net return on investment of the wholesalers and retailers were 0.23 and 0.32 .

Table 2: Estimated monthly marketing costs and returns of pineapple marketing

\begin{tabular}{lll}
\hline Item/Respondents & Wholesalers & Retailers \\
\hline Total Revenue (TR) & $19,677,000.00$ & $4,550,880.00$ \\
Variable Costs: & $11,523,000.00$ & $2,956,800.00$ \\
Purchases & $4,160,000.00$ & $363,840.00$ \\
Transportation & $41,440.00$ & $17,760.00$ \\
Storage & $72,960.00$ & $24,720.00$ \\
Loading & $72,960.00$ & $24,720.00$ \\
Off-loading & $26,880.00$ & $15,200.00$ \\
Security & $\mathbf{1 5 , 8 9 7 , 2 4 0 . 0 0}$ & $\mathbf{3 , 4 0 3 , 0 4 0 . 0 0}$ \\
Total Variable Costs & $3,779,760.00$ & $741,840.00$ \\
Gross Margin (TR-TVC & & \\
Fixed Costs: & $120,320.00$ & $26,400.00$ \\
Rent & $38,400.00$ & $14,400.00$ \\
Local Government Rate & $4,193.44$ & $2,121.92$ \\
Equipment depreciation & $\mathbf{1 2 6 , 9 1 3 . 4 4}$ & $\mathbf{4 2 , 9 2 1 . 9 2}$ \\
Total fixed Cost & & \\
Net marketing income (NMI) & $3,616,846.56$ & $1,104,918.08$ \\
NMI = GM- TFC) & $34,777,37$ & $10,624.21$ \\
Mean NMI = NMI/N & $\mathbf{1 6 , 0 2 4 , 1 5 3 . 4 4}$ & $\mathbf{3 , 4 4 5 , 9 6 1 . 9 2}$ \\
Total Costs & & \\
Net Return on investment (NROI) & 0.23 & 0.32 \\
NROI = NMI/TC & & \\
\hline Source: Field survey, 2016 & &
\end{tabular}

Source: Field survey, 2016

This indicates that for every one naira, the wholesalers and retailers made 23 kobo and 32 kobo respectively. This indicates that the business is profitable. However, the retailers' net return on investment is higher than that of the wholesalers. A possible reason for this is because the wholesalers incurred bigger marketing costs due to their bigger trade volume. However, the wholesalers' smaller net returns on investment seem compensated with higher profit due to their bigger trade volume and quick turn over.

The result agrees with the findings of Iwuchukwu, Nwobodo and Udoye (2017) that the crop has a ready market and good production prospect but requires production improvement using various strategies which include use of organic manure, provision of irrigation system for off-season production, funding pineapple research and provision of extension service. Olayinka (2013) in a study of profitability and constraints of pineapple production in Osun State, Nigeria found that the return on investment of the 
Creative commons User License: CC BY-NC-ND

Abstracted by: EBSCOhost, Electronic Journals Service (EJS), Google Scholar, Journal Seek, Scientific Commons,

Food and Agricultural Organization (FAO), CABI and Scopus
Journal of Agricultural Extension

Vol. 22 (2) June, 2018

ISSN(e): 24086851; ISSN(Print); 1119944X

http://journal.aesonnigeria.org

Email: editorinchief@aesonnigeria.org

farmers was only 8 kobo. Although the study was conducted in a different State, it indicates that the farmer's share of the consumer spending was small. It further reveals that the middlemen's profit given above in this study is very much higher than that of the pineapple farmers. Shortage of improved planting materials, low level of production technology and perishable nature of the fruits were the reasons given for the low profit of the pineapple farmers (Olayinka, 2013).

\section{Problems of Pineapple Marketing}

Figure 1 shows that the most serious problems encountered by pineapple marketers in the study area were high transportation cost (40.4) and lack of fund to increase business scale $30.8 \%$. This result on lack of fund to increase business scale agrees with Iwuchukwu, Nwobodo and Udoye (2017) that the crop has a ready market and good production prospect but requires production improvement. Investigation on the respondent's mode of transportation shows that the majority of them $(65.4 \%)$ use commercial buses as their means of pineapple haulage, $19.2 \%$ used wheel barrow while $15.4 \%$ use commercial motor cycle and tri-cycle. High transportation cost experienced by the marketers is understandable because of the high petroleum products prices and high costs of vehicle maintenance. Added to the above, is the long distances the traders especially the wholesalers had to cover while in search of pineapple stock.

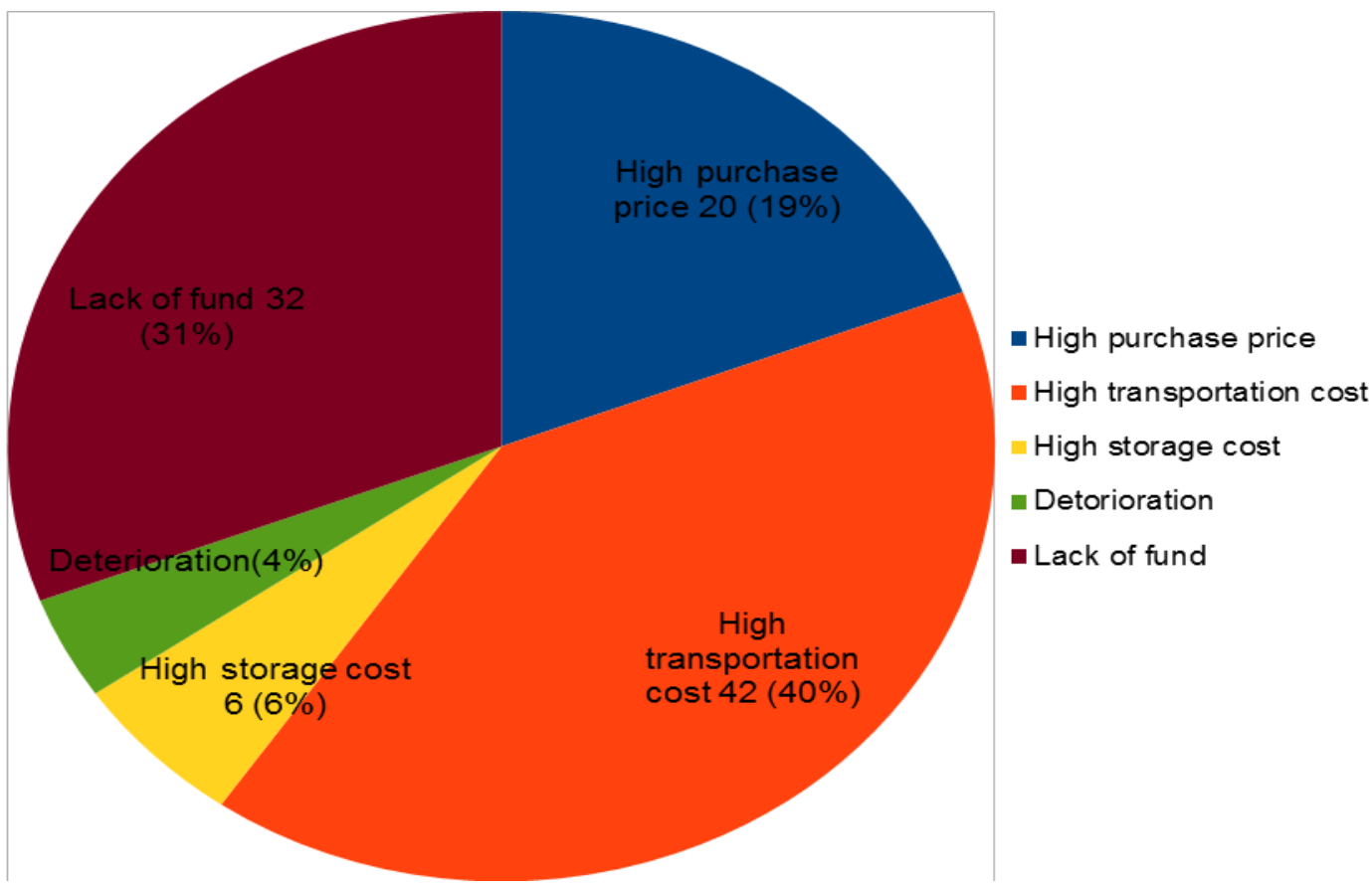

Figure 1 Distribution of the respondents according to marketing problems 
Creative commons User License: CC BY-NC-ND

Abstracted by: EBSCOhost, Electronic Journals Service (EJS), Google Scholar, Journal Seek, Scientific Commons,

Food and Agricultural Organization (FAO), CABI and Scopus

\section{Sources of Pineapple Marking Fund}

The problem of lack of fund to increase pineapple business scale is understandable because only a negligible proportion (5.8) of the respondents accessed bank loans while the majority sourced their capital from personal savings as shown in Table 3 . This result is in agreement with that of Iwuchukwu, Nwobodo and Udoye (2017) that provision of effective micro-credit facilities, incentives and subsidies are some of the strategies for improving pineapple production.

Table 3: Distribution of the respondents according to capital sources

\begin{tabular}{ll}
\hline Capital sources & Percentage $(\mathrm{n}=104)$ \\
\hline Personal savings & 63.5 \\
Cooperative Societies & 13.5 \\
Relatives & 17.3 \\
Banks & 5.8 \\
\hline
\end{tabular}

\section{Source: Field survey, 2016}

\section{Conclusion and Recommendations}

The study revealed that: pineapple business in Anambra State is profitable because it respectively returned 23 and 32 kobo for every one naira spent by wholesalers and the retailers; the main constraint of the traders were high transportation cost and lack of fund to increase pineapple business scale.

Provision of bank credit facilities for pineapple marketing is required.

The National Directorate of Employment (NDE), traders' associations, nongovernmental Organizations (NGOs) and others should arrange to educate and encourage the unemployed, traders and entrepreneurs on pineapple fruits business opportunities.

\section{References}

Abbott, J. C. and Makeham J. C. (2000). Agricultural Economics and Marketing in the Tropics, $\quad$ Longman Group (F. E) Ltd Hong Kong.

Technical Centre for Agricultural and Rural Cooperation CTA (2007). Preserving green leafy vegetables and fruits. The ACP-EU Technical Centre for Agricultural and Rural Cooperation (CTA), Practical Guid series, No 8, Wageningen, Netherlands. 
Creative commons User License: CC BY-NC-ND

Abstracted by: EBSCOhost, Electronic Journals Service (EJS), Google Scholar, Journal Seek, Scientific Commons,

Food and Agricultural Organization (FAO), CABI and Scopus
Journal of Agricultural Extension

Vol. 22 (2) June, 2018

ISSN(e): 24086851; ISSN(Print); 1119944X

http://journal.aesonnigeria.org

Email: editorinchief@aesonnigeria.org

Technical Centre for Agricultural and Rural Cooperation CTA (2007). Processing Tomatoes. The ACP-EU Technical Centre for Agricultural and rural Cooperation (CTA), Practical Guid series, No 12, Wageningen, Netherlands.

Enibe, D. O, S.A.N.D. Chidebelu, E. A Onwubuya, C. Agbo and A. A. Mbah (2008) Policy Issues in the Structure, Conduct and performance of banana market in Anambra State, Nigeria, Journal of Agricultural Extension, 12, 2, 32-40.

Idise, Okiemute Emmanuel (2012) Studies of wine produced from pineapple (Ananas cosmosus). International Journal for Biotechnology and Molecular Biology Research, 3, 1 .

Iwuchukwu, J. C., E. C. Udoye and Onwubuya, E. A.(2013). Training needs of pineapple farmers in Enugu State, Nigeria. Journal of Agricultural Extension, 17, $189-99$.

Iwuchukwu, J. C., C. E. Nwobodo and Udoye, E. C. (2017). Problems and prospects of pineapple production in Enugu State, Nigeria. Journal of Agricultural Extension, 21, 1, 167-180.

Maurice Waite (2012). Oxford English Dictionary. Oxford University Press, Great Britain.

Olayinka, I. B. (2013). Profitability and constraints of pineapple production in Osun State, Nigeria. Journal of Horticultural Research 21, 2, 59-64.

Sally, Dibb., Lyndon Simkin., William, M. Pride and Ferrell., O. C (2006). Marketing Concepts and Strategies. Houghton Mifflin Company, Boston, USA. 